\title{
Seasonal changes in water quality index at different sites of Gomti river, Lucknow
}

\author{
Nimisha Srivastava* and R.C. Arya \\ Department of Botany, Meerut College, Meerut (U.P.) \\ *E-mail: nimisha.peehu@gmail.com
}

\begin{abstract}
Anthropological activities affect the aquatic and terrestrial ecosystem, which leads to a loss of many species, consumer - resource imbalance, niche modification of the species as well as bring changes in the species composition of some regions. The condition of water in the Gomti river has been depleting day by day, besides many agencies working on the cleaning action plan. Gomti river receives various types of pollutants such as in industrial waste, household waste, agriculture waste, fertilizers, pestisides, sewage wastes. As a consequence of these dumped pollutants the water quality index still not up to the mark. An exploratory study regarding the physico-chemical analysis has been done at five sites i.e. Hanuman Setu, Kudia ghat, Gau ghat, Barrage and Manjhi Ghat at three different seasons i.e. summer, winter and rainy. The dissolved oxygen of the river usually remains low, it was found to be lowest in summer season, got a little bit better in rainy season but still it reached to an average level in winter. Water hycinth is present in every ghat in a very large amount and is a cause of reduced dissolved oxygen in river. It is important for fishes and other aquatic organism to live, it is an important indicator of water quality, and its lower level indicates high level of pollution in river Gomti. Nitrate always remained in range in all the three seasons but its level was very low. Ammonical nitrogen also remained in range in all the three seasons but its level was very low at Manghi ghat (0.081-0.084). In winter, summers and in rainy season it was in range but towards lower side. The water $\mathrm{pH}$ of Gomti remained alkaline throughout the year and at Manghi ghat the $\mathrm{pH}$ remained exactly the same throughout the year. The level of phosphate was high at all the ghats throughout the year. The level of silica was in range throughout the year. The Hanuman setu recorded the highest level of Silica in summers (21.08). Though the government and other agencies are working on it to make the river alive. But still a lot has to be done for the river by all of us.
\end{abstract}

Keywords: Seasonal changes, quality index, Gomti river, Lucknow.

Paper cited: Srivastava, N. and Arya, R.C. (2020). Seasonal changes in water quality index at different sites of Gomti river, Lucknow. South Asian Journal of Food Technology and Environment, 6(1): 913-916.

\section{Introduction}

The Gomti river originates from Gomat taal near Madho Tanda, Pilibhit, India. It extends to $960 \mathrm{Km}$ through Uttar Pradesh and meets Ganges near Saidpur Kaithi, $27 \mathrm{~km}$. from Varanasi (Gomti river, Wikipedia).

After $240 \mathrm{Km}$. the Gomti enters Lucknow, flows through the city for about 12 $\mathrm{km}$. Due to discharge of industrial effluents, domestic and sewage water, agricultural water and decaying material of human, animals and plants has polluted Indian rivers day by day. (Asthana et al., 1997). At the downstream end, the Gomti Barrage converts the river into a lake. Chemicals in the form of fertilizers, pesticides, insecticides used in the agricultural fields or industries find their destination into the rivers thus posing a threat to the existing flora and fauna, nature to their aquatic bodies as well as human health. Another ritual in which thousands of large and small idols of Goddess Durga and Lord Ganesh are immersed in the river water. (Tiwari and Kisku et al.,2016) A numbers of colour and toxic chemicals leach from the idols and disperse in the river water thus entering the 
food chains and affecting the human health. Too much growth of water hycinth in the river is also a cause of lowered DO level.

It receives agricultural runoff from its vast catchment area spread over 10 districts directly or through out in course, receives untreated raw waste water and industrial effluents through its five major tributaries and more than 40 drains in Lucknow (UPPCB, 2013).

\section{Study Area}

In the present study, seasonal variations on six different parameters at five different locations were studied in Lucknow i.e. Manghi Ghat, Gau Ghat, Kudiya Ghat, Hanuman Setu and Barrage. The water index for six different Scales i.e. $\mathrm{pH}$, Dissolved Oxygen, Nitrate, Ammonical Nitrogen, Silica and Phosphorous at three different seasons of the year were studied. In rainy season in month of September.-October 2018, in Winter season of January-February 2019 and in Summer Season of May-June, 2019.

\section{Method and methods}

In the present study seasonal variations in some chemical and physical parameter of Gomti River were studied. The sampling was done in Rainy Season September-October 2018, Winter season in January-February, 2019 and in Summer Season in May-June, 2019. The Samples were collected and submitted to Uttar Pradesh Pollution Control Board for the analysis. The Silica testing was done at CSIR-IITR, Lucknow and samples were analyzed.

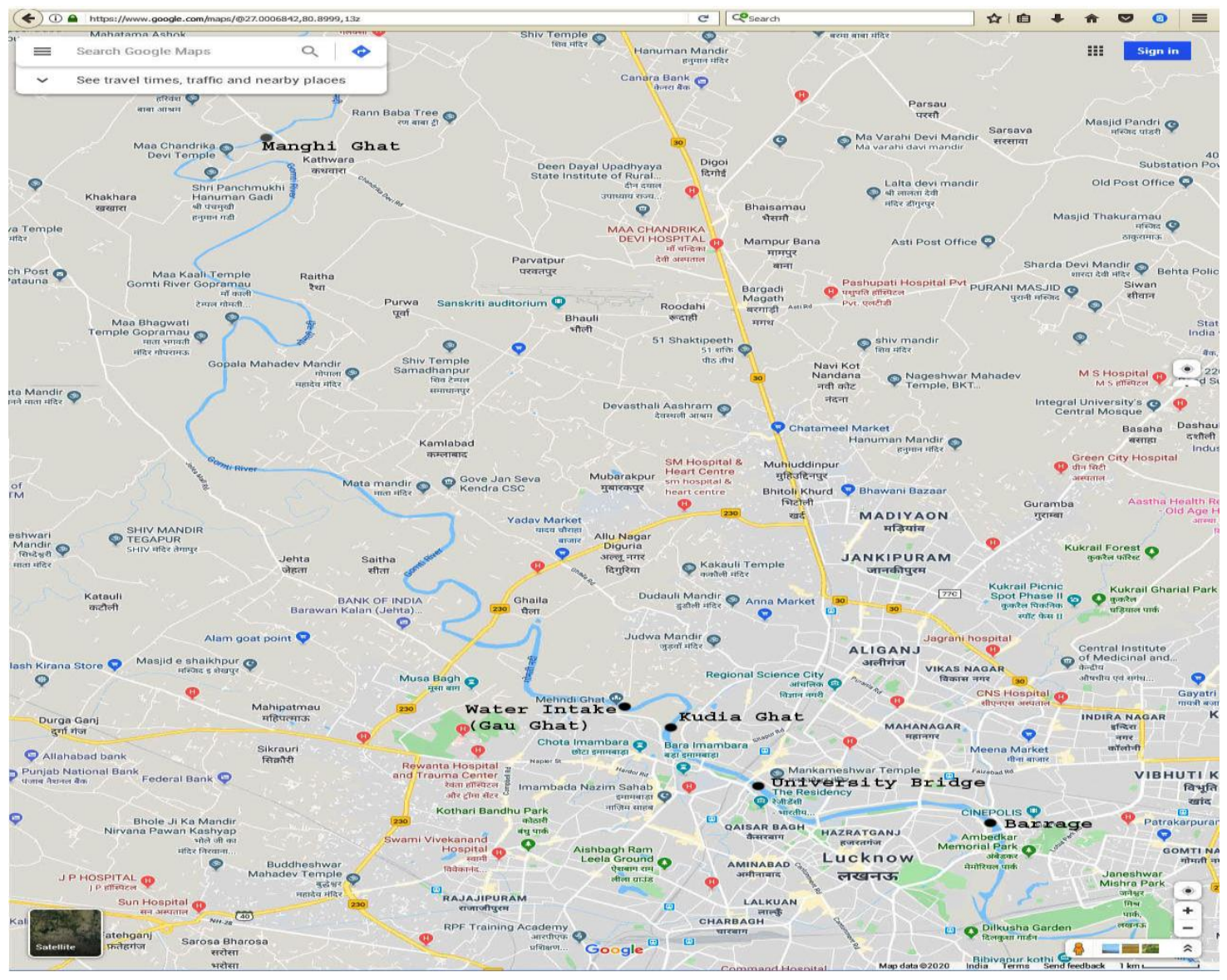

Fig. 1: Gomti Map of Lucknow showing the Ghats studied 


\section{Result and discussion}

In present study total six physiochemical parameters were analyzed and they are listed in the Table 1 given below according to the variation found in different season.

\section{pH}

During Rainy season in October, 2018 $\mathrm{pH}$ of river remained alkaline and did not varied much $(8.04 \pm 7.79)$. Manghi Ghat showed highest $\mathrm{pH}$ while Barrage showed the lowest. In summers also the river water remained alkaline and $\mathrm{pH}$ range varied from $(8.78 \pm 7.48)$. Manghi Ghat showing highest pH while Kudiya Ghat lowest. In winters the $\mathrm{pH}$ ranged between $(8.81 \pm 7.86)$. Gau Ghat had the highest $\mathrm{pH}$ and Barrage the lowest. In this year's study the alkaline nature of Manghi Ghat did not varied much it showed the highest $\mathrm{pH}$ throughout the year.

According to Trivedi (2016), the $\mathrm{pH}$ was also found to be alkaline in Gomati river.

\section{Dissolved Oxygen}

The DO in 2018 rainy season ranged (7.5 \pm 2.9$)$. It was highest at Manghi Ghat and lowest at Barrage in winters and summers it was again highest at Manghi Ghat. In winters it ranged from $(12.5 \pm 1.5)$ and in summers (9.04 \pm 0.41$)$, in winters Barrage recorded the lowest while in summers Hanuman setu recorded the lowest. Throughout the season Manghi Ghat D.O. range was good and in normal range.

The DO range of the river has increased showing good sign. The sampling done in 2008 and 2009 (Srivastava and Srivastava, 2011) showed that the DO range was low in river in Lucknow.

\section{Phosphate}

Phosphate range went higher at all the ghats studied, except Manghi Ghat in which phosphate was in range. In rainy season Manghi ghat had the lowest phosphate range and Gau ghat the highest $(0.60 \pm 0.06)$. In winter season Manghi Ghat had the lowest phosphate level and Barrage recorded the highest $(2.10 \pm 0.397)$. In summer Manghi Ghat recorded the lowest phosphate level and phosphate range highest being at Kudiya Ghat $(4.1 \pm 0.45)$. The studies performed by Chandra et al., (2013) also showed high phosphate level throughout the season and same is in present position.

\section{Nitrate}

Nitrate levels were in range in rainy season, showing its highest at Barrage (3.7 \pm 1.4) and lowest at Manghi Ghat. Nitrate was in level in summers being highest at Kudiya Ghat and lowest at Manghi Ghat $(5.4 \pm 0.74)$

In winter nitrate was 0.348 at Manghi ghat and absent in water at the rest of the stations but according to the studies done in January by Chandra et al., (2013), the nitrate levels were high in river but now they are in range.

\section{Ammonical Nitrogen}

Ammonical Nitrogen remained in range throughout the year recorded lowest at Hanuman setu and highest at Barrage in rainy season $(0.7 \pm 0.17)$. During winter season ammonical nitrogen was lowest at Manghi Ghat (0.081) and was highest at Barrage (1.83 $\pm 0.081)$ and in summers also Manghi Ghat showed lowest range and was highest at Hanuman Setu (1.74 \pm 0.084$)$. Ammonical Nitrogen was found to be high few years back but now it's in range.

\section{Silica}

The range of Silica remained in range throughout the season. In rainy season, silica was highest at Manghi Ghat and lowest at Barrage $(8.48 \pm 5.88)$. In winter it was highest at Barrage and lowest at Gau ghat showing a range of $(5.31 \pm 2.04)$. In Summers Silica was highest at Hanuman Setu and lowest at Manghi Ghat (21.09 \pm 7.29$)$. 
Table 1: Comparative Study Chart of Three Seasons

\begin{tabular}{|c|c|c|c|c|c|c|c|}
\hline S. No. & $\begin{array}{c}\text { Parameters } \\
\text { (range) }\end{array}$ & Season & $\begin{array}{c}\text { Manghi } \\
\text { Ghat }\end{array}$ & Barrage & $\begin{array}{c}\text { Water } \\
\text { Intake } \\
\text { (Gau Ghat) }\end{array}$ & $\begin{array}{c}\text { Kudia } \\
\text { Ghat }\end{array}$ & $\begin{array}{c}\text { Hanuman } \\
\text { Setu }\end{array}$ \\
\hline 1 & $\mathrm{pH}$ & Rainy & 8.04 & 7.66 & 7.99 & 7.90 & 7.79 \\
& $(6.5-8.5)$ & Winter & 8.81 & 7.86 & 8.88 & 8.32 & 8.16 \\
& Summer & 8.78 & 7.57 & 8.76 & 7.48 & 7.50 \\
\hline 2 & DO & Rainy & 7.50 & 2.90 & 5.70 & 5.00 & 3.90 \\
& $(6.5-8.0 \mathrm{mg} / \mathrm{l})$ & Winter & 12.50 & 1.50 & 9.00 & 5.50 & 5.40 \\
& & Summer & 9.04 & 3.25 & 5.40 & 0.78 & 0.41 \\
\hline 3 & Phosphate & Rainy & 0.06 & 0.47 & 0.60 & 0.55 & 0.48 \\
& $(0.05-0.1 \mathrm{mg} / \mathrm{l})$ & Winter & 0.397 & 2.10 & 0.485 & 0.781 & 1.20 \\
& & Summer & 0.451 & 0.611 & 0.672 & 4.10 & 1.004 \\
\hline 4 & Nitrate & Rainy & 1.40 & 3.70 & 1.80 & 1.60 & 1.50 \\
& $($ Upto $10 \mathrm{mg} / \mathrm{l})$ & Winter & 0.348 & ND & ND & ND & ND \\
& & Summer & 0.742 & 4.190 & 2.70 & 5.40 & 2.40 \\
\hline 5 & Ammonical & Rainy & 0.23 & 0.47 & 0.23 & 0.20 & 0.17 \\
& Nitrogen & Winter & 0.81 & 1.83 & 0.411 & 1.05 & 1.21 \\
& $(2-6 \mathrm{mg} / \mathrm{l})$ & Summer & 0.084 & 0.847 & 0.762 & 1.46 & 1.74 \\
\hline 6 & Silica & Rainy & 8.48 & 5.88 & 6.81 & 6.05 & 7.00 \\
& $(5-25 \mathrm{mg} / \mathrm{l})$ & Winter & 3.70 & 5.31 & 2.04 & 3.16 & 3.72 \\
& & Summer & 7.29 & 10.54 & 8.37 & 9.45 & 21.08 \\
\hline
\end{tabular}

\section{Conclusion}

River water pollution is not only an aesthetic problem, but a serious economic and public health problem as well. Periodical monitoring of the water quality is thus required to assess the condition of surface water. This will be helpful in saving the river from further degradation. After studying the five ghats at three different seasons the conclusion at which I reached is that phosphate level is very high of river, due to leaching of detergents from industries, drains and washing of cloths. Dissolved oxygen is towards lower side due to high growth of water hycinth and eutrophication because of phosphate and nitrate reaching the river. A lot has to be done by government and other agencies to clean up the water.

\section{References}

1. Asthana R.K., Singh, K.N. and Murtaza S.I. (1997). Deterioration of Physio Chemical and Biological characters of lori water affected by Urban Water. $U$. Scientist Physical Science, 9(9): 101-104.

2. Chandra, S., Rawat, S.K., Garg, S.K. and Singh, R.P. (2013). Responses of Trapa Natans against the soaring concentration of nitrate and phosphate in a Tropical river Gomti in Lucknow City, India. Journal of Recent advances in Applied Sciences, 28: 78-81.

3. Gomti river, Wikipedia.

4. Trivedi, P. (2016). An assessment of water quality of Gomti river particular relevant to physio-chemical characteristics, pesticides and heavy metals. International Journal of Engineering Research and Application, 6(9): 66-75.

5. Srivastava, A. and Srivastava, S. (2011). Assessment of Physio-chemical properties and sewage pollution indicator bacteria in surface water of River Gomti in Uttar Pradesh. International Journal of Environmental Sciences, 2(1): 325-336

6. Tiwari, M. and Kisku, G.G. (2016). Impact Assessment of Gomti River Water Quality after Immersion of idols during Durga Utsav. Biochemistry and Analytical Chemistry, 5(3): 2161-1009.

7. UPPCB (2013): http/www.india waterportal.org/news/report Uttar Pradesh pollution - control board - uppcb reveals deteriorating condition Gomti river.

$\begin{array}{ll}\text { Received } & \text { : February, 2020 } \\ \text { Revised } & \text { : March, 2020 } \\ \text { Published } & \text { : June, 2020 }\end{array}$

